\title{
Usaha Pembibitan Sapi Perah Di Universitas Andalas
}

\section{The Business of Dairy Cattle Breeding in Andalas University}

\section{E. Nurdin dan Andri}

Fakultas Peternakan Universitas Andalas

Kampus Unand Limau manis, Padang 25163

Email: ellyza_n@yahoo.com

(Diterima: 22 Februari 2012; Disetujui: 6 April 2012)

\begin{abstract}
The business of Dairy Cattle Breeding in Universiy of Andalas is a science and technology program for innovation and creativity in Campus (Ib-IKK). This is a joint program of HEDG and University of Andalas. In 2012, it has just entered the second year of three-years scheduled. The five dairy cattle breed have brought from Lembang (West Java) at the first year program. And now, Ib-IKK have 3 lactation cows, 2 pregnant cows, 1 bull and 3 heifers. This businesses are prioritized to establish the availability of dairy cow, until the business is ready to supply of dairy cattle breed for the farmer in West Sumatera. This time, the program sold a fresh milk, pasteurized milk and agro-tourism, which is managed by undergraduate student of Faculty of Animal Science, University of Andalas.
\end{abstract}

Keywords: Ib-IKK, Dairy Cattle, Breeding, University of Andalas

\section{PENDAHULUAN}

Program pengembangan peternakan yang dijalankan pemerintah dalam usaha pembangunan peternakan sapi perah di Indonesia adalah dengan meningkatan populasi dan daya produksi susu yang lebih baik. Hal ini mengingat kebutuhan susu masih diatas kemampuan produksi sapi-sapi yang ada sehingga kesenjangan ini terpaksa dipenuhi oleh susu import.

Kemampuan produksi ditentukan juga oleh populasi ternak sapi perah yang ada. Oleh sebab itu program pemerintah saat ini yang dituangkan dalam Petunjuk Teknis Pengembangan Pembibitan Sapi Perah Tahun 2012 yang dikeluarkan oleh Dirjen Peternakan adalah meningkatkan populasi dan produktivitas ternak perah serta terbentuknya kawasan sumber bibit melalui kelompok pembibit.

Kebutuhan peternak akan bibit sapi perah di Indonesia pada umumnya dan Pulau Sumatera pada khususnya Aceh, Sumatera Utara, Sumatera Barat, Riau, Bengkulu, Jambi dan Lampung untuk meningkatkan populasi masih mendatangkan bibit sapi perah dari luar daerah dan luar negeri seperti dari Propinsi Jawa Barat dan Australia demikian pula halnya dengan kebutuhan produk susu. Kondisi ini menyebabkan harga bibit menjadi sangat tinggi. Sehigga membuka peluang besar bagi sektor swasta maupun perguruan tinggi untuk berkiprah mengembangkan sektor peternakan sapi perah dibidang pembibitan maupun industri susu.

Kampus Universitas Andalas terletak di Bukit Karamunting, Padang, Sumatera Barat dengan ketinggian $350 \mathrm{~m}$ dpl. Fakultas Peternakan Universitas Andalas memiliki areal lahan untuk peternakan seluas 25 ha yang dapat menampung dan menghidupi 250 ekor sapi dewasa (250 ST). Dari keseluruhan lahan, 5 ha lahan diantaranya sudah ditanami hijauan jenis rumput gajah dan saat ini sedang dilakukan perluasan lahan rumput di areal tersebut. Sedangkan diareal peternakan sudah tersedia kandang permanen untuk sapi perah yang bisa menampung lebih kurang 50 ekor sapi dewasa.

Unit sapi perah berada dibawah UPTFakultas Peternakan Unand yang juga membawahi seluruh unit ternak unggas, ternak potong, dan tekhnologi hasil ternak 
Oleh sebab itu Fakultas Peternakan Universitas Andalas sebagai lembaga pendidikan berkewajiban untuk ikut berperan dalam menunjang program pemerintah untuk mensukseskan Program Peningkatan Swasembada Pangan Masyarakat dan Program Sumbar sebagai Kolam Susu.

Universitas Andalas sebagai sebuah institusi pemerintah di bidang pendidikan selama ini merupakan institusi yang memiliki reputasi dan memiliki tingkat kepercayaan yang tinggi dari masyarakat. Analisis kekuatan dan Kelemahan serta Analisis Kesempatan dan Ancaman yang dihadapi dapat dilihat pada tabel 1 dan 2., merupakan bahan pertimbangan dan pendukung yang diperlukan dalam pengembangan program IbIKK.

Tabel 1. Analisis Kekuatan dan Kelemahan Usaha Pembibitan Sapi Perah di Unand

\begin{tabular}{clcl}
\hline No & \multicolumn{1}{c}{ Kekuatan } & No & \multicolumn{1}{c}{ Kelemahan } \\
\hline 1 & $\begin{array}{l}\text { Kepercayaan masyarakat yang tinggi terhadap } \\
\text { Universitas Andalas }\end{array}$ & 1 & $\begin{array}{l}\text { Kampus belum dikenal sebagai pusat } \\
\text { usaha (bussines centre) }\end{array}$ \\
2 & $\begin{array}{l}\text { Belum ada pembibitan sapi perah di Prop. } \\
\text { Sumatera Barat khususnya dan pulau } \\
\text { Sumatera pada umumnya }\end{array}$ & 2 & $\begin{array}{l}\text { Pengalaman dan jiwa wirausaha SDM } \\
\text { di kampus belum kuat }\end{array}$ \\
3 & $\begin{array}{l}\text { Fasilitas UPT Peternakan yang terdiri atas } \\
\text { kandang, lahan dan padang rumput yang luas } \\
\text { dan sangat memadai }\end{array}$ \\
4 & $\begin{array}{l}\text { Tersedianya pakar dari berbagai bidang ilmu } \\
\text { Peternakan }\end{array}$ \\
5 & $\begin{array}{l}\text { Semangat mempersiapkan diri dalam } \\
\text { menghadapi otonomi PT }\end{array}$ \\
\hline Sumber: Nurdin dan Andri (2011,2012)
\end{tabular}

Sumber: Nurdin dan Andri $(2011,2012)$

Tabel 2. Analisis Kesempatan dan Ancaman yang Dihadapi Usaha Pembibitan Sapi Perah di Unand

\begin{tabular}{|c|c|c|c|}
\hline No & Kesempatan & No & Ancaman \\
\hline 1 & $\begin{array}{l}\text { Potensi Sumatera Barat sebagai sentra sapi } \\
\text { perah dan susu diluar pulau Jawa, karena } \\
\text { kondisi di pulau Jawa sudah tidak } \\
\text { memungkinkan }\end{array}$ & 1 & $\begin{array}{l}\text { Kebijakan di Perguruan Tinggi (PT) } \\
\text { yang sering berubah-ubah. }\end{array}$ \\
\hline 2 & $\begin{array}{l}\text { Kebutuhan bibit sapi perah di Propinsi. } \\
\text { Sumatera Barat cukup tinggi. }\end{array}$ & 2 & $\begin{array}{l}\text { Persaingan dengan industri pembibitan } \\
\text { sapi perah multinasional }\end{array}$ \\
\hline 3 & $\begin{array}{l}\text { Permintaan akan susu organik dan produk } \\
\text { olahannya yang bermutu baik sangat tinggi } \\
\text { dan mengalami neraca negatif sehingga } \\
\text { didatangkan dari luar Sumbar }\end{array}$ & 3 & $\begin{array}{l}\text { Anggapan dari Pemda dan Swasta } \\
\text { maupun masyarakat bahwa Perguruan } \\
\text { Tinggi tidak boleh berbisnis. }\end{array}$ \\
\hline 4 & $\begin{array}{l}\text { Permintaan akan pupuk padat dan cair } \\
\text { organik sangat tinggi dalam mendukung } \\
\text { peternakan terpadu ramah lingkungan }\end{array}$ & & \\
\hline 5 & $\begin{array}{l}\text { Kerjasama dengan Pemda, Lembaga } \\
\text { Keuangan, Swasta dan Internasional }\end{array}$ & & \\
\hline
\end{tabular}

Sumber: Nurdin dan Andri $(2011,2012)$ 
Program nantinya akan melahirkan suatu model atau konsep pengembangan usaha ternak sapi perah yang baik yang dapat di terapkan di Indonesia. Penerapan konsep ini akan memberikan nilai tambah produk secara efisien pada setiap tahap usaha. Bagian terpenting dari keterpaduan usaha pembibitan sapi perah ini adalah termanfaatkan secara optimal semua produk ternak sapi mulai dari anak sampai kotoran (faeces dan urine) sehingga dapat menjadi percontohan peternakan sapi perah ramah lingkungan (zero weist).

Model pengembangan usaha pembibitan sapi perah yang akan diterapkan di kampus Universitas Andalas adalah membentuk unitunit usaha yang melibatkan kelompok mahasiswa, organisasi, masyarakat atau kelompok masyarakat yang berminat dengan sapi perah dan komoditasnya. Pemasaran dilakukan melalui mitra dengan peternak sapi perah baik yang berskala besar maupun kecil. Konsep pengembangan pembibitan sapi perah ini akan menjadi Hak Kekayaan Intelektual/ HKI Fakultas Peternakan Universitas Andalas.

\section{Manfaat program secara lokal maupun nasional.}

\section{Manfaat Secara Lokal}

Akademis :

- Menerapkan hasil penelitian dosendosen atau mahasiswa dibidang ternak perah dan yang terkait dilingkungan Fakultas Peternakan.

- Meningkatkan kemampuan meneliti yang mengarah pada penerapan hasil penelitian yang terpakai di dunia usaha

- Meningkatkan kerjasama penelitian antara perguruan tinggi dan swasta

Ekonomis :

- Unit Ib-IKK ini dapat menjadi sumber pendapatan bagi Fakutas Peternakan khususnya dan Universitas Andalas pada umumnya.

- Memberikan kesempatan dan pengalaman bekerja bagi mahasiswa dalam berbisnis ternak sapi perah dan produknya.

- Meningkatkan kemampuan kewira- usahaan dosen dan mahasiswa

- Memberikan lapangan pekerjaan masyarakat disekitar kampus Universitas Andalas dengan berkembangnya usaha ternak sapi perah

- Meningkatkan kerjasama yang saling menguntungkan antara Fakultas Peternakan dengan pihak swasta yang bergerak di bidang Peternakan dan Industri Pangan.

\section{Manfaat Secara Nasional}

- Untuk mengembangkan kegiatan bisnis dibawah Laboratorium Produksi Ternak Perah dalam rangka kemandirian Fakultas Peternakan Universitas Andalas.

- Unit Ib-Ikk ini akan menghasilkan model bagi Fakultas Peternakan lain di Indonesia atau fakultas-fakultas teknis lain dalam mengembangkan unit usaha komersil yang produktif dalam upaya kemandirian Universitas.

- Meningkatkan jiwa kewirausahaan mahasiswa dan dosen dengan memanfaatkan hasil IPTEKS yang dapat diterapkan secara komersil.

\section{Pelaksanaan Program}

Program Ib-IKK Pembibitan Sapi Perah di Universitas Andalas tahun II ini dimulai dari 5 ekor induk FH yang terdiri dari 3 ekor betina bunting diatas 4 bulan dan 2 ekor betina dara siap kawin yang didatangkan dari Peternakan Sapi Perah di lembang, jawa Barat. Sapi induk ini merupakan pabrik penghasil anak yang dirawat untuk menjadi bibit sapi perah sebagai komoditas utama di tahun ke III. Pada tahun ke II ini calon bibit yang akan dihasilkan pada tahun III berjumlah 4 ekor dari 5 ekor calon bibit yang seharusnya dimiliki yang terdiri dari 1 ekor jantan umur 10 bulan, 1 ekor betina umur 9 bulan, 1 ekor betina umur 5 bulan, 1 ekor betina umur 1 bulan, sedangkan 1 ekor lagi anak dilahirkan dalam kondisi mati. Sehingga calon bibit yang ada berjumlah 4 ekor.

Program Ib-IKK saat ini berada dalam taraf perawatan dan pembesaran anak-anak 
yang dilahirkan oleh sapi-sapi induk pada tahun I (calon bibit). Penjualan produk utama berupa bibit baru akan dilaksanakan di tahun ke 3.

Penjualan produk tambahan yaitu susu segar sudah berjalan dengan pasar kelompokkelompok masyarakat dan mahasiswa. Produk dijual dalam bentuk susu segar dengan kemasan 1 liter yang dijual dalam kondisi segar dan beku. Disamping itu produk susu juga diproduksi dalam bentuk susu pasteurisasi aneka rasa yaitu coklat, vanilla dan strawberi yang dijual dalam bentuk cup. Produksi susu sebanyak 10 liter/ekor/hari, dipasarkan sebagai susu segar kepada konsumen seharga Rp 7 000,- per liter dan untuk susu pateurisasi seharga Rp 3000 per cup.

Produk tambahan lainnya adalah pupuk organic yang memiliki potensi sangat baik tetapi belum dipasarkan karena masih memenuhi kebutuhan padang rumput di areal peternakan di Universitas Andalas diproduksi sebanyak $1600 \mathrm{~kg}$ per bulan. Setelah kondisi padang rumput telah baik, pupuk akan dijual seharga Rp 3 000,- per kg. Seluruh produk akan di label "Andalas Dairy Farm" dan akan diurus merk dagangnya pada tahun ke 3 . Produk yang dihasilkan akan mengikuti SNI (2011)

Kontrol terhadap pemeliharaan dan penanganan sapi perah dilakukan dengan melaksanakan recording terhadap masingmasing sapi perah. Recording berisi catatan pertambahan bobot badan seminggu, konsumsi ransum setiap hari dan catatan kesehatan. Evaluasi dilakukan setiap bulan, apabila terjadi penurunan bobot badan , penurunan jumlah konsumsi ransum dilakukan evaluasi penyebabnya dan dilakukan perbaikan terhadap penyebabnya.

Pada tahun II kontribusi Ib-IKK kepada institusi saat ini masih dalam bentuk menunjang proses pendidikan yaitu dalam bentuk kesempatan magang, penelitian, praktek lapangan dan praktikum bagi mahasiswa dalam rangka menyiapkan skill mahasiswa dibidang ternak perah. Karena pada tahun ke II ini program Ib-IKK masih merupakan usaha baru, program belum memperoleh keuntungan secara in cash. Tetapi dihitung dari asset ternak yang ada, maka program Ib-IKK memiliki asset ternak senilai Rp $110000 \quad 000,-$. Setelah program ini berjalan dengan baik maka pada tahun III, program Ib-IKK Pembibitan Sapi Perah akan memberikan kontribusi kepada Universitas Andalas sebagai suatu usaha yang mandiri.

\section{KESIMPULAN}

Pada tahun II program belum menghasilkan produk utama yaitu bibit sapi perah dan kontribusi Ib-IKK kepada institusi saat ini masih dalam bentuk menunjang proses pendidikan yaitu dalam bentuk kesempatan magang, penelitian, praktek lapangan dan praktikum bagi mahasiswa dan siswa siswi di kota Padang dalam rangka menyiapkan skill mahasiswa dibidang ternak perah dan wawasan siswa/siswi dari Taman kanakKanak hingga Sekolah Menengah.

Program ini sangat mendukung pengembangan unit RGA di Perguruan Tinggi, untuk itu perlu dikembangkan secara berkesinambungan.

\section{UCAPAN TERIMAKASIH}

Pada kesempatan ini, ucapan terimakasih kami sampaikan kepada:

1. Direktorat Jenderal Pendidikan Tinggi (Dikti) Departemen Pendidikan Nasional sebagai penyandang dana.

2. Rektor universitas Andalas, sebagai penyandang dana.

3. Lembaga Penelitian dan Pengabdian Kepada Masyarakat Universitas Andalas Padang dan staf yang menyiapkan administrasi dan kelengkapan lainnya.

4. Dekan Fakultas Peternakan Universitas Andalas

5. Unit Pelaksana Tekhnis (UPT) Fakultas Peternakan Universitas Andalas

6. Rekan - rekan civitas akademika yang telah bahu membahu sehingga terlaksananya kegiatan ini. 


\section{DAFTAR PUSTAKA}

Davies, H.L. 1982. Nutrition and Growth Manual. Australian Universities International Development Program (AUIDP). Australian Vice Chancellors Committee. Sydney. p: 20 - 25; 40 - 46.

Dictionary of Natural Products. 1992. Type of Compound Index. Special Index. Vol.7. Chapman \& Hall. London.

Dirjen Peternakan. 2012. Petunjuk Teknis Pengembangan Pembibitan Sapi Perah. Kementrian Pertanian

National Research Council (NRC). 2001. Nutrient Requirement of Dairy Cattle. Seven ${ }^{\text {th }}$ revised Ed. Washington, D.C. : National Academy Press.

Nurdin, E. 2007. The Effect of receptalum of Sunflowers addition in the rations to decrease Mastitis on subclinical Mastitis Holstein Dairy Cows. Journal of The Indonesian Tropical Animal Agriculture. Vol.32 No.2 : 76-79.

Nurdin, E. 2007. Pengaruh Pemberian Bunga Matahari dan Bioplus Terhadap Solid Non Fat, Total Solid dan $\mathrm{pH}$ Susu Sapi Perah Penderita FH. Animal Production.Vol.9. No.2, Hal. 79-81.

Nurdin, E. 2011. Manajemen Sapi perah. Graha Ilmu. Yogyakarta.

Nurdin, E. dan Andri. 2011. Ib-IKK Pembibitan Sapi Perah di Universitas Andalas Tahun I. Laporan Pengabdian
Pada Masyarakat Multi Tahun IbIKK. Direktorat Jenderal Pendidikan Tinggi, Departemen Pendidikan Nasional.

Nurdin, E. dan Andri. 2011. Ib-IKK Pembibitan Sapi Perah di Universitas Andalas Tahun II. Laporan Pengabdian Pada Masyarakat Multi Tahun Ib-IKK. Direktorat Jenderal Pendidikan Tinggi, Departemen Pendidikan Nasional.

Nurdin, E and H. Susanti. 2009. Pemanfaatan Bahan Antioksidan Alami Terhadap Produktivitas Sapi Perah Penderita Mastitis. Laporan Penelitian Hibah Kompetitif Penelitian Sesuai Prioritas Nasional batch III. Direktorat Jenderal Pendidikan Tinggi, Departemen Pendidikan Nasional.

Nurdin, E and Arief. 2009. The Effectivity of Cumin as Natural Anti-oxidant to Improve Rumen Ecology of Mastitis Dairy Cow's. Animal Production.Vol.11.No.3 hal 160-164.

Nurdin,E. dan T.Amelia. 2011. Formulasi Konsentrat Ternak perah dengan Penambahan bahan antioksidan jintan (Cuminum cyminum L.). Laporan Hibah HKI. Direktorat Jenderal Pendidikan Tinggi, Departemen Pendidikan Nasional.

Standar Nasional Indonesia (SNI). 1998. Badan Standarisasi Nasional-BSN, Jakarta. 